\title{
DR.152
}

DOE/NASA CONTRACTOR

DOE/NASA CR-161306 REPORT

\section{INDOOR TEST FOR THERMAL PERFORMANCE OF THE SUNMASTER EVACUATED TUBE (LIQUID) SOLAR COLLECTOR}

Prepared by

Wyle Laboratories

Solar Energy Systems Division

Huntsville, Alabama 35805

Under subcontract with IBM, Federal Systems Division, Huntsville, Alabama 35807

Contract NAS8-32036 with

National Aeronautics and Space Administration

George C. Marshall Space Flight Center, Alabama 35812

For the U. S. Department of Energy

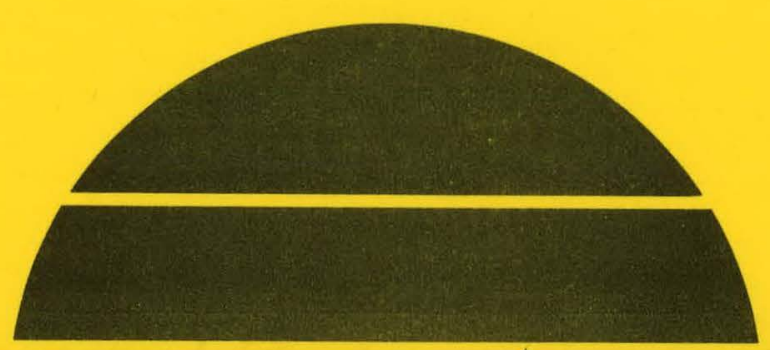

\section{U.S. Department of Energy}




\section{DISCLAIMER}

This report was prepared as an account of work sponsored by an agency of the United States Government. Neither the United States Government nor any agency Thereof, nor any of their employees, makes any warranty, express or implied, or assumes any legal liability or responsibility for the accuracy, completeness, or usefulness of any information, apparatus, product, or process disclosed, or represents that its use would not infringe privately owned rights. Reference herein to any specific commercial product, process, or service by trade name, trademark, manufacturer, or otherwise does not necessarily constitute or imply its endorsement, recommendation, or favoring by the United States Government or any agency thereof. The views and opinions of authors expressed herein do not necessarily state or reflect those of the United States Government or any agency thereof. 


\section{DISCLAIMER}

Portions of this document may be illegible in electronic image products. Images are produced from the best available original document. 
NOTICE

This report was prepared to document work sponsored by the InIted States Government. Nelther the United States nor 1 is agents the Unfted States Department of Energy, the United States Nat1onal Aeronautics and Space Administration, nor any federal employees, nor any of their contractors, subcontractors or the1r employees, make any warranty, express or implied, or assume any legal 11ab1lity or responstb1lity for the accuracy, completeness, or usefulness of any informat1on, apparatus, product or process disclosed, or represent that its use would not infringe privarely owned rights. 


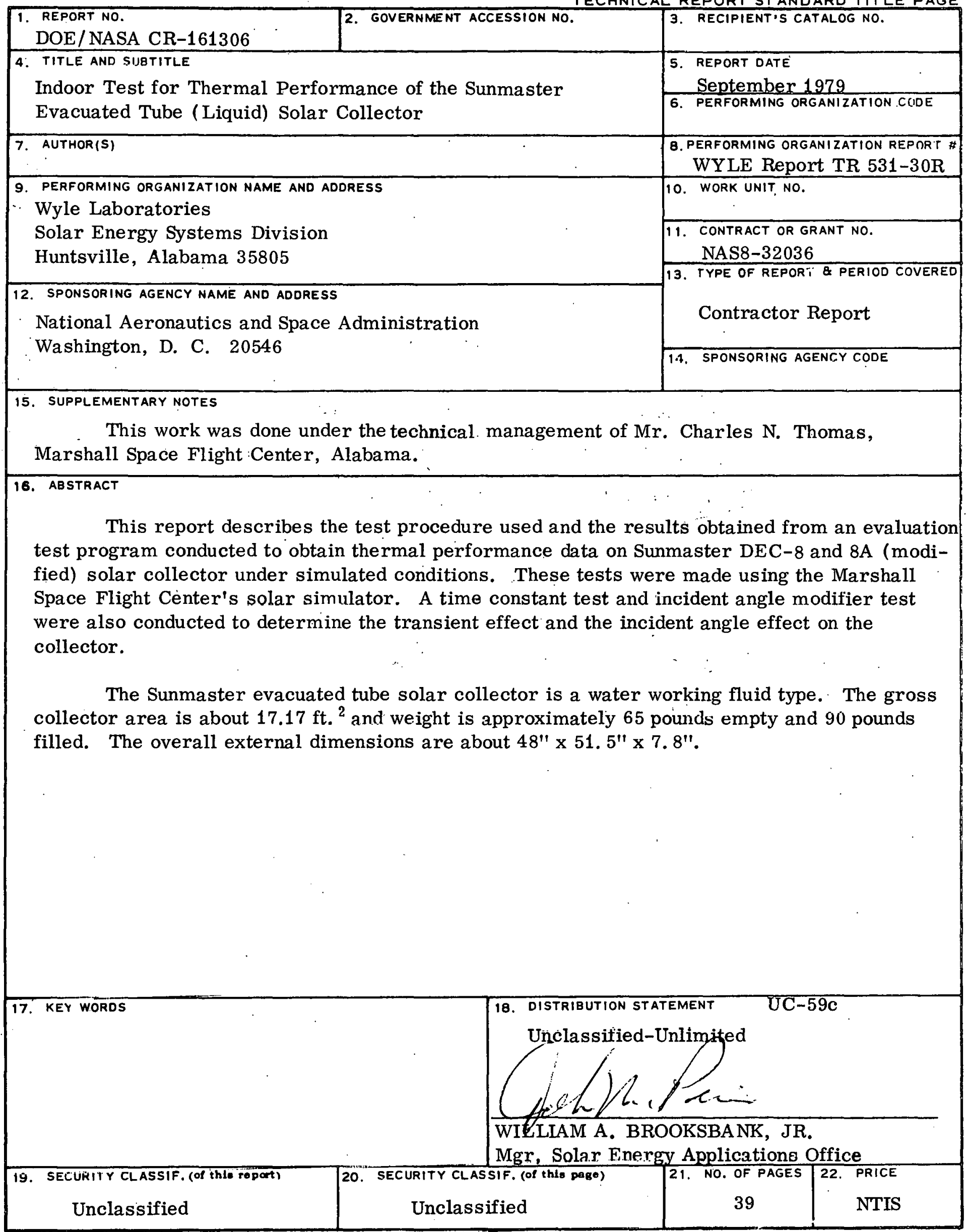




\section{ACKNOWI.F:DGMENT}

The test program covered by this report was requested by Mr. B. Wiesenmaier (EEOl) and Mr. W. A. Hagen (FA33) of the George C. Marshall Space Flight Center. Mr. Wiesenmaier generated the test requirements and furnished technical $\mathrm{co}^{-}$ ordination relative to application of ASHRAE 93-77 and the MSFC Solar Simulator to testing vacuum tube collectors. 
TABLE OF CONTENTS

Page No.

1.0

PURPOSE

1

2.0

REFERENCES

1

3.0

COLLECTOR DESCRIPTION

1

4.0

SUMMARY

2

5.0

TEST CONDITIONS AND TEST EQUIPMENT

5.1 Ambient Conditions

5.2 Instrumentation and Equipment

5.3 Data Systems

6.0

TEST REQUIREMENTS AND PROCEDURES

6.1 Collector Preconditioning and Stagnation Test

6.2 Collector Time Constant Test

6.3 Collector Thermal Efficiency Test 9

6.4 Incident Angle Modifier Test 11

6.5 Fill and Drain and Hot Fill Test 12

7.0

ANALYSIS OF RESULTS

7.1 Thermal Performance Test

13

7.2 Time Constant Test

16

7.3 Incident Angle Modifier Test

17

TABLE I

TABLE II

TABLE III

TABLE IV
THERMAL PERFORMANCE TEST DATA FOR THE DEC-8 SUNMASTER COLLECTOR

THE DEC-8A SUNMASTER COLLECTOR

FOR THE DEC-8A SUNMASTER COLLECTOR

BREAKAGE CONDITIONS

FILL TUBE

SUNMASTER COLLECTOR CALCULATED ALL DAY EFFICIENCY 
TABLE OF CONTENTS (Continued)

Page No.

Figure 1 Schematic of the Sunmaster collector, Indicating Instrumentation 26

Figure 2 Thermal Efficiency of the DEC-8 Sunmaster collector

Figure 3

Efficiency of the Sunmaster DEC-8 Configuration as a Function of Inlet Temperature for a water Flow Rate of $.175 \mathrm{GPM}$

Figure 4

Thermal Efficiency of the DEC-8A

Sunmaster Collector

Figure 5

Efficiency of the Sunmaster DEC-8A Configuration as a Function of Inlet Temperature

Figure 6

Time Constant Test for the Sunmaster DEC-8A Configuration at 0.175 GPM

Figure 7

Incident Angle Modifier for the Sunmaster DEC-8A Configuration

Figure 8

Typical Temperature Response at the Maximum Temperature Location for the Sunmaster DEC-8 Configuration

Fiqure 9

Typical Flux Map During the Sunmaster Testing

Figure 10 Singular Tube Exposure Versus Fill Rate Noting Tube Breakage for the Hot Fill Test of the Sunmaster Collector 
The purpose of this document is to present the test procedures used during the performance of an evaluation test program to obtain performance data on the sunmaster solar collector under simulated conditions.

The test was performed utilizing the MSFC solar simulator in accordance with the test requirements specified in Reference 2.1 and the procedures contained in Reference 2.2 , except where noted in the test procedure to accommodate test requirements peculiar to the sunmaster collector.

2.0

2.1

2.2

2.3 3.0
REFERENCES

ASHRAE $93-77$

MTCP-FA-SHAC -400

NBSIR $78-1305 \mathrm{~A}$
Method of Testing to Determing the Thermal Performance of Solar Collectors

Procedure for Operation of the MSFC Solar Simulator Facility

Provisional Flat Plate Solar Collector Testing Procedures: First Revision

COLLECTOR DESCRIPTION

Manufacturer :

Manufacturer's

Address :

Model Number:

Serial Number:

Type:

Working Fluid:

Gross Collector

Area, $\mathrm{Ft}^{2}$ :

Uverail external dimensions :

Collector glazing:

Weight:
Sunmaster Corporation

12 Spruce Street Corning, New York 14830

Sunmaster DEC-8 (Original) Sunmaster DEC-8A (Modified)

$\begin{array}{ll}\text { DEC-8 } & 000118 \\ \text { DEC- }-8 A & 002949\end{array}$

Evacuated Tube

water

17.17

width, inches $\quad 48.0$

Lerigth, inches $\quad 51.5$

Thickness, inches $\quad 7.8$

Aperture area, $\mathrm{ft}^{2} \quad 14.0$

Evacuated tube

Empty, lbs. $\quad 65.0$

Water Filled, lbs. 90.0 
This test program was conducted to evaluate the performance of a Sunmaster liquid, evacuated tube solar collector under simulated conditions. A schematic of the collector array is shown in Figure 1. The test conditions and the data obtained for the thermal performance tests are listed in Tables I and II. Table I contains results for the DEC-8 configuration, which had a one-inch diameter outlet manifold with copper orifices. During the testing, erratic flow was observed at the inclination angle of 6 degrees, corresponding to the latitude of a special application. The manufacturer was aware of problems at this inclination angle and supplied a modified version; DEC-8A, which has a 1-1/4 inch diameter outlet manifold and pyrex glass or ifices. Table II contains the test dat.a for the DEC-8A configuration. The DEC-8 configuration was tested in an open loop and the DEC-8A configuration was tested in a closed loop at 15 PSIG. Graphic presentations of the data contained in Tables I and II are shown in Figures 2 and 3 for the DEC-8 configuration and in Figures 4 and 5 for the DEC- 8 A configuration. A time constant test and an incident angle modifier test were also performed to determine the transient effects of the solar incidence angle on the collector. The results of these tests are shown in Figures 6 and 7 , respectively, with the incident angle modifier test data given in Table III. Several special tests were requested for this collector. A non-standard stagnation test was performed to determine maximum tube temperatures for various levels of solar insolation. Figure 8 contains the transient tube responses for the stagnation test. Each evacuated tube operates as an independent flat plate; therefore, a threc-point flux map was performed for each tube. A typical flux mar is shown in Figure 9, indicatiny that non-uniformities are well within the allowable limits for solar simulators. A hot fill test was conducted to determine the possibility of breakage in the event of an accidental hot fill. Several breakages did occur, but all were at conditions above typical operation. Table IV shows

the hot tube fill condition, and Figure 10 provides a summary of. the hot till test resulta. In the event that a particular delta temperature promotes the tube breakages, Table IV was developed by interpolating for tube temperatures from the stagnation plots in Figure 8 . Although there is no apparent relationship between flow rate and breakage, al. of the breakages did occur at a delta temperature of more than $600^{\circ} \mathrm{F}$.

The standard configuration for the Sunmaster collector is with no cover. However, a Lexan cover was used to cover the tubes in case of breakage during the hot fill test. The indicated solar flux levels are corrected values 
compensating for the transmissivity loss through the Lexan cover.

The only common ground for comparing overall collector performance should be the "all day efficiency" rather than $F_{R} \propto \tau$. No standard practice has been established, but each collector should be evaluated for space heating, domestic hot water and solar cooling or process heat applications at a nominal location. This would assist the solar designer in choosing the most efficient collector for a particular application. Evacuated tube collectors are effective for solar cooling applications; therefore, according to the procedure in. NBSIR 78-1305A, an all day efficiency for the Sunmaster was calculated for a typical solar cooling application. The selected site dependent data in conjunction with test results used in this determination are shown in Table $V$. 


\subsection{TEST CONDIMTONS AND IEST EQUIPMENT}

$5.1 \quad$ Ambient Conditions

5.2 Instrumentation and Equipment

All test equipment and instrumentation used in the performance of this test program comply with the requireinents of MSFC-MMI-5300.4C, Metrology and Calibration. Figure ]. contains instrumentation identification and data acquisition connection data. Instrumentation locations on the legt loop and collector are also depicted in Figure 1. A listing of tile equipment lised in cauh test. follows.

Apparatus

Pyranometer

Liquid Loop

Directional Anemometer

Flow Meter

Thermocouples

Platinum Resistance

The rmome ter

Strip Chart Recorder

Fans

sol.ar simulater

Pressure Gauge
Manufacturer/Model

Eppley - PSP

MSFC Supplied

Supplied by AMC

Foxboro/1/2-2 82098B

Type $\mathrm{T}$

$\mathrm{Hy} \cdots \mathrm{Cal}$

Mosley 680

MSFC Supplied

MSFC Supplied

U. S. Gauge Co/Ashcroft

\section{Range/Accuracy}

$0-800 \mathrm{BTU} / \mathrm{Ft}^{2}$.

Hr Class I

$.1-1.2 \mathrm{GPM}$

$0-30 \mathrm{MPH}$

$.1-1.12 \pm 18$ GPM

$-100+700 \pm 2^{\circ} \mathrm{F}$

$0-1000^{\circ} \mathrm{F} \pm 0.5^{\circ} \mathrm{F}$

$5-500 M V \pm 28$

$\mathrm{N} / \mathrm{A}$

See SHC 3006

$0-60$ HSIG \pm

1 PSIG

All transducers, with the exception of the Eppley PSP pyranomcler used in recording test data, are calibrated by either NASA Or AMC calibration laboratories as required by MSFC MMI 5300.4C. The PSP pyranometer was calibrated by the manufacturer. The stated accu-. racy of individual transducers reflects the overall expected accuracy through the data acquisition system. 
A Doric Digitrend 220 digital output data logger was used to record all test data. A formal systems error analysis was not done; confidence in printout accuracies was established by installing calibrated "parallel" transducers and direct readouts at key points in the system and comparison checks were performed from time to time before, during and after tests. The results of such checks together with a review of the data for anomalies indicated that the data presented is suitable for the purpose intended. 
6.0. TEST REQUIREMENTS AND PROCEDURES

6.1 Collector Preconditioning and Stagnation Test

6.1 .1 Requirement

Preconditioning of the Sunmaster collectors is not required. Rather than monitor temperatures for a standard stagnation test, maximum tube temperatures at steadystate conditions for several insolation levels were obtained.

$6: 1.2 \quad$ Procedure

1. Mount test specimen on test table at a $6^{\circ}$ angle with reference to the floor.

2. Assure that the simulator lamp array is adjusted to an angle of $6^{\circ}$ with reference to the floor.

3. Using the procedure contained in Reference 2.2, align the test table such that the test specimen and lamp array centerlines coincide and the distance between the specimen and the plane of the lamp array lenses is nine feet.

4. Insulate all liquid lines.

5. Connect instrumentation leads to data acquisition system in accordance with Figure 1 .

6. Assure that the data acquisition system is operational.

7. Perform sensor accuracy verification tests.

8. Power up the solar simulator according to Refeience 2.2 and perform a flux map at top, middle and bottom of each tube.

y. Establish a solar flux level of approximately 300 BTU/ $\mathrm{Hr}-\mathrm{Ft}^{2}$.

10. Record data at one minute intervals until steady state conditions are achieved.

11. Repeat steps 9 and 10 with approximate llux lovels. of 325,350 , and $375 \mathrm{BTU} / \mathrm{Hr}-\mathrm{Ft}^{2}$.

12. Upon completion of testing, power down the simulator according to Refercnce 2.?.

$6.1 .3 \quad$ Results

The results for the special stagnation test are shown graphicaily in Figure 8 . 


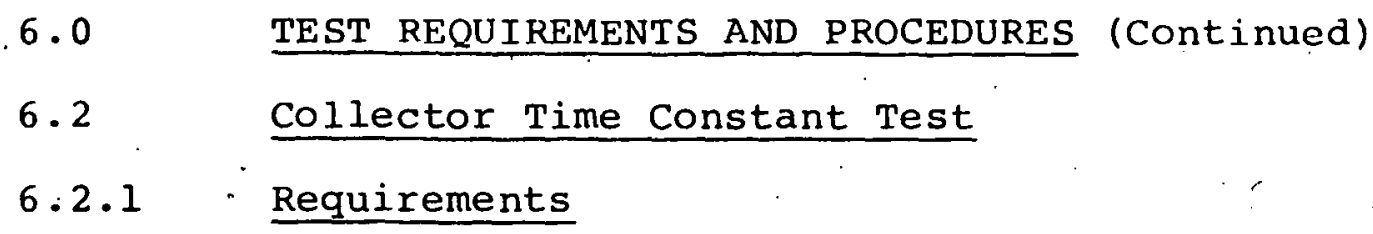

The collector time constant shall be determined by abruptly reducing the solar flux to zero. This will be done with the inlet temperature adjusted to within $\pm 2^{\circ} \mathrm{F}$ of ambient while the liquid is flowing at 0.175 GPM.

The differential temperature across the collector shall be monitored to determine the time required to reach the condition of:

$$
\frac{\Delta \mathrm{T}(\mathrm{t})}{\Delta \mathrm{T}_{\mathrm{i}}}=.368
$$

where $\Delta T(t)$ is the differential temperature at time $t$ after the solar flux is reduced to zero and. $\therefore T_{i}$ is the differential temperature prior to the power down of the solar simulator. The liquid to be used as the collector heat transfer medium shall be as specified by the manufacturer. If this liquid is not specified, use water as the fluid.

The following data will be recorded for the test:

(1) Solar flux.

(2) Ambient temperature.

(3) Inlet liquid temperature.

(4) Collector differential temperature.

(5) Liquid flow rate.

(6) Specified heat transfer medium.

6.2.2 Procedure

1. Adjust the liquid (water) flow rate to $0.175 \mathrm{GPM} . *$

2. Adjust the inlet temperature to ambient $\pm 2^{\circ} \mathrm{F}$.

3. Power up the solar simulator and establish a solar flux level of $300 \mathrm{BTU} / \mathrm{Ft}^{2} \cdot \mathrm{Hr}$.

4. Establish wind speed of $7.5 \mathrm{mph}$.

5. Record data for ten minutes at above stabilized conditions.

6. Power down solar simulator.

7. Record the change of $\Delta T$ across the collector.

* This is the manufacturer's recommended flowrate for this test. 
6.2.3 Results

The results obtained during the time constant test are shown in Figure 6 . 


\subsection{TEST REQUIREMENTS AND PROCEDURES (Continued) \\ 6.3 Collector Thermal Efficiency Test \\ 6.3.1 Requirements}

Utilizing the MSFC Solar Simulator and the portable liquid loop, parametric performance evaluation data shall be recorded of the following test variables and conditions. The liquid to be used is the manufacturer's recommended heat transfer fluid. If not specified, the test shall be performed using water as the working fluid.

Variable/Condition

(1) Collector inlet liquid temperature differential above existing ambient temperature level

(2) Collector outlet liquid temperature

(3) Incident solar flux level

(4) Liquid flow rate through collector

(5) Wind speed

(6) Ambient air temperature
Requirement

$$
0^{\circ} \mathrm{F}, 25^{\circ} \mathrm{F}, 50^{\circ} \mathrm{F}, 75^{\circ} \mathrm{F}
$$$$
\text { and } 100^{\circ} \mathrm{F}
$$

Measured data

250,300 , and 350 $\mathrm{BTU} / \mathrm{Hr} \cdot \mathrm{Ft}^{2}{ }^{\circ} \mathrm{F}$

$0.175 \mathrm{GPM}$

$7.5 \mathrm{MPH}$

Existing room condition

\subsubsection{Procedure}

1. Mount test specimen on test table at a $6^{\circ}$ angle with reference to the floor.

2. Assure that simulator lamp array is adjusted to an angle of $6^{\circ}$ with reference to the floor.

3. Using the procedure contained in Reference 2.2, align the test table so the test specimen's vertical centerline coincides with the vertical centerline of the lamp array and the distance from the loop of the test specimen to the lens plane of the lamp array is 9 feet.

4. Insulate all liquid lines.

5. Connect instrumentation leads to data acquisition system in accordance with Figure 1.

6. Assure that data acquisition system is operational. 
6.0 TEST REQUIREMENTS AND PROCEDURES (Continued)

6.3 Collector Thermal Efficiency Test (Continued)

6.3.2 Procedure (Continued)

7. Perform sensor accuracy verification tests.

8. Establish required wind speed.

9. Start liquid flow loop and establish the required flow rate.

10. Establish the required inlet temperature.

11. Power up solar simulator in accordance with Reference 2.2 and establish the required solar flux level, performing a flux map. at top, middle and bottom of each tube.

12. Record data for a minimum of five minutes at these stabilized conditions.

13. Repeat Steps 9 through 12 for all inlet temperatures.

14. Obtain sufficient data at 10,15 and $45^{\circ}$ inclination angles to determine effect on performance.

15. Jpon completion of testing, power down simulator and 1 iquid loop in accorance with Reference 2.2 .

$6.3 .3 \quad$ Results

The thermal efficiency tests were conducted for the DEC8 and DEC-8A configurations. The results for these tests are contained in Tables. I and II and are presented graphically in Figures 2 through 5. The DEC-8 collector was tested in an open loop system. The DEC-8A collector was tested in a closed loop at 15 PSIG. 


\subsection{TEST REQUIREMENTS AND PROCEDURES (Continued) \\ 6.4 Incident Angle Modifier Test}

\subsubsection{Requirements}

Due to flow and drain down requirements, the collector could not be tilted; therefore, the lamp array was adjusted to $15^{\circ}, 30^{\circ}$ and $45^{\circ}$ with respect to the solar collector surface. The liquid flow rate shall be 0.175 GPM. with the inlet temperature controlled to within $\pm 2^{\circ} \mathrm{F}$ of ambient. The insolation rate shall be $300 \mathrm{BTU} / \mathrm{Ft}{ }^{2} \cdot \mathrm{hr}^{\circ}$. The liquid to be used is the manufacturer's recommended fluid. If not specified, the tests shall be performed using water as the heat transfer medium. The following data shall be recorded during the tests.

(1) Lamp array tilt angles.

(2) Ambient air temperature.

(3) Collector inlet liquid temperature.

(4) Collector outlet liquid temperature.

(5) Collector differential temperature.

(6) Collector differential pressure.

(7) Incident solar flux level.

(8) Liquid flow rate through the collector.

\subsubsection{Procedure}

1. Set up lamp array at required tilt angle.

2. Establish required flowrate.

3. Establish required inlet temperature.

4. Establish solar simulator flux level at $300 \mathrm{BTU} / \mathrm{Ft}^{2} \cdot \mathrm{Hr}$ and measure the flux levels at 24 locations on the collector surface and record on data sheet.

5. Record data for ten minutes at above stabilized conditions.

6. Repeat above steps as necessary to obtain required data for each tilt angle.

6.4.3 Results

The results of the incioent angle modifier test are presented in Table III and are shown graphically in Figure 7 . 
Requirements

The test will be performed utilizing the solar simulator. The collector will be mounted at a $6^{\circ}$ inclination angie with respect to horizontal, such that the outlet is $1 / 8$ inch lower than the opposite side to allow the manifold to drain. Utilizing special tubes with an observation window, fill the collector, with no solar insolation, at flow rates of $0.35 \mathrm{GPM}$ and $0.075 \mathrm{GPN}_{1}$, monitoring the time required to fill the collector. Drain the full collector, monitoring the drain timc, as a result of gravity drain. After the fill and drain times have been determined, bring the empty collector to stagnation steady-state temperatures at flux levels of 300,325 and $375 \mathrm{BTU} / \mathrm{Hr} \cdot \mathrm{Ft}^{2}$, and fill the collector with ambient temperature water at flow rates of $0.20,0.25,0.30$, and 0.35 GPM. Data to be recorded is listed below:

1. Insolation rate.

2. Ambient temperature.

3. Inlet temperature.

4. Absorber surface temperatures at 3 or 4 locations.

5. Flow rate.

6.5.2 Procedure

1. Mount test specimen as described above.

2. Conrect and check out instrumentation.

3. Record above data.

$6.5: 3 \quad$ Resủlts

Results of the fill time tests were 9.2 minutes and 38 minutes for 0.35 and 0.075 GPM flow rates, respectively. The drain time was six minutes, but will vary with suction heads on the inlet and with the collector inclination angle.

The hot fill tests were performed with two differcnt sets of tubes. The first set had gone through ctagnation testing, and five were broken as a result of the hot fill. A new set of tubes was installed, and three more tubes broke. The results of the hot fill tests are shown in Figure 10 . Table. IV lists the flux levels, flow rates and temperature difference between the inlet liquid and the tube stagnation temperature at the conditions when breakage occurred. 
7.0 ANALYSIS OF RESULTS

7.1 Thermal Performance Test

The analysis of data contained in this report is in accordance with the National Bureau of Standards recommended approach. This approach is outlined below.

The efficiency of a collector is stated as:

$\eta=\frac{q_{u} / A}{I}=\frac{\dot{m} C_{t f}\left(t_{f, e}-t_{f, i}\right)}{I}$

where:

qu = rate of useful energy extracted from the solar collector (BTU/Hr)

A. $=$ Gross collector area $\left(F t^{2}\right)$

I = Total solar energy incident upon the plane of the solar collector per unit time per unit area ( $\mathrm{BTU} / \mathrm{Hr} \cdot \mathrm{Ft}^{2}$ )

in $=$ Mass flow rate of the transfer liquid through the collector per unit area of the collector $\left(\mathrm{Lbm} / \mathrm{Ft}^{2} \cdot \mathrm{Hr}\right)$

$C_{t f}=$ Specific heat of the transfer liquid (BTU/Lb. ${ }^{\circ} \mathrm{F}$ ) $t_{f, e}=\begin{aligned} & \text { Temperature of the transfer liquid leaving the } \\ & \text { collector }\left({ }^{\circ} \mathrm{F}\right)\end{aligned}$

$t_{f, i}=$ Temperature of the transfer liquid entering the collector $\left({ }^{\circ} \mathrm{F}\right)$

Rewriting Equation (1) in terms of the total collector area yield:

$n=\frac{(\dot{m} A) C_{t f}\left(t_{f, e}-t_{f, i}\right)}{(I A)}=\frac{\dot{M} C_{t f}\left(t_{f, e}-t_{f, i}\right)}{P_{i}}$

Notice that:

$P_{i}=I A=$ Total power incident on the collector $\dot{\mathrm{m}} \mathrm{A}=\dot{\mathrm{M}}=$ Total mass flow rate through the collector

Therefore, $\dot{M} C_{t f}\left(t_{f, e}-t_{f, i}\right)=$ Total power collected by the collector. 
7.1 Thermal Performance Test (Continued)

Substitution in Equation (2) results in:

$n=\frac{\text { Pabs }}{\text { Pinc }}$

where:

Pabs $=$ Total collected power

Pinc $=$ Total incident power

This value of efficiency is cxpressed as a percentage by multiplying by $1 \cap n$. This expression for percent efficiency is:

Collector Efficiency $=\frac{\text { Pabs }}{\text { Pinc }} \times 100$

or from Equalion (2), collector efficiency is defined by the equation:

qEf $=\frac{\dot{M} C_{t f}\left(t_{f, e}-t_{f, i}\right)}{\text { Pinc }} \times 100$

Each term in Ecruation (5) was measured and recorded independently during the test. The calculated values of efficiency were determined at sixty-second intervals. The mean value of efficiency was determined over a ten minute period during which the test conditions remained in a quasi-steady state: Each ten -minute period constitutes one "data point" as is graphically depicted on a plot of percent. efficiency. versus

$$
\left.\left(t_{i}-t_{a}\right) / I\right)
$$

where:

$t_{i}=$ Liquid inlet temperature ( $\left.{ }^{\circ} \mathrm{F}^{\prime}\right)$

$t_{a}=$ Ambient temperature $\left({ }^{\circ} \mathrm{F}\right)$

$I$ = Indident. flux per unit area (BTU/Hr. $\mathrm{Ft}^{2}$ )

The abscissa term $\left(\left(t_{i}-t_{a}\right) / I\right)$ was used to normalize the effect of operating at slightly different values of $I, t_{i}$ and $t_{a}$. The results are found in Figures 2 and 4. Die to the excellent insulative properties of tine evacuated tube, and considerable data scatter, the best curve fit is a first order polynomial given by:

Efficiency $=a_{0}+a_{1} J^{\prime}$ 
7.1 Thermal Performance Test (Continued)

where:

$$
\mathcal{J}=\left(\mathrm{T}_{\mathbf{i}}-\mathrm{T}_{\mathrm{a}}\right) / \mathrm{I}
$$

and the coefficients are determined to be:

Flow Rate (GPM)

$a_{0}$

$a_{1}$

$\mathrm{a}_{0}$

$a_{1}$

\subsection{5}

0.411

$-0.145\}$

$\left.\begin{array}{r}0.391 \\ -0.224\end{array}\right\}$
DEC - 8

DEC-8A 
Two methods are proposed by ASHRAE 93-77 for conducting a time constant test; however, due to facility 1 imitations, the first method was used. This method consisted of shading the collector and maintaining a constant flow rate and inlet temperature while obtaining data.

According to the definition of time constant given in 9377 , it is the time required for the ratio of the differential temperature at time $\tau$ to the initial differential Lemperature to reach .368 , when solar insolation is reduced to zero. It can be expressed as:

$$
\frac{T_{f, e, i}-T_{f, i}}{T_{f, e, i n i}-T_{f, i}}=.368
$$

If the inlet liquid temperature cannot be controlled to equal the ambient air temperature, then the following equation must be used

$$
\frac{F_{R} U_{L}\left(T_{f, i}-T_{a}\right)+\frac{\dot{m} C p}{\overline{A g}}\left(T_{f, e, \tau}-T_{f, i}\right)}{F_{R} U_{L}\left(T_{f, i}-T_{a}\right)+\frac{\dot{m} C P}{\frac{A g}{(}}\left(T_{f, e, i n i}-T_{f, i}\right)}=.368
$$

where:

$$
\begin{aligned}
& T_{f}, e, \tau \text { Exit Iiquid temperature at time } \tau \\
& T_{f, i} \quad \text { Inlet liquid temperature } \\
& \mathrm{T}_{\mathrm{f}, \mathrm{e}, \mathrm{ini}} \text { Initial exit liquid temperature } \\
& \dot{\mathrm{m}} \text { Liquita mass flow rate, Lb/Hr } \\
& \mathrm{C}_{\mathrm{p}} \text { Specific heal of liquid, BTU/Lb }{ }^{\circ} \mathrm{F} \\
& \text { Ag Gross collector area, } \mathrm{ft}^{2} \\
& \mathrm{~F}_{\mathrm{R}} \mathrm{U}_{\mathrm{L}} \quad \text { Negative of the slope determined frum }
\end{aligned}
$$

The inlet temperature was maintained within $\pm 2^{\circ} \mathrm{F}$ of the ambient, hence equation (1) was ised for evaluation. From Figure 6 the time constant was determined to be 12 minutes. 
7.3 Incident Angle Modifier Test

Two methods are proposed by ASHRAE 93-77 for incident angle modifier tests. For the MSFC Solar simulator Facility, only method 1 (tilting the collector is apnlicable. However, due to the flow and drain down design of this collector, it was necessary to tilt the solar array instead of the collector. The lamp array could not be adjusted to $60^{\circ}$; therefore, the angles of $0^{\circ}, 15^{\circ}$, $30^{\circ}$ and $45^{\circ}$ to the normal of the collector surface were used.

According to $93-77$, the incident angle modifier is defined as

$$
K \alpha \tau=\frac{h}{F_{R}(\tau \alpha) n}
$$

where $n=$ efficiency at tilted angle.

$$
\begin{aligned}
F_{R}(d \tau) n= & \text { Intercept of efficiency curve } \\
& \text { at normal incident angle without } \\
& \text { a cover plate }
\end{aligned}
$$

For equation (1) to be applicable, the inlet liquid temperature must be controlled to within $\pm 2^{\circ} \mathrm{F}$ of the ambient air temperature. In cases where the inlet liquid temperature cannot be controlled to within $\pm 2^{\circ} \mathrm{F}$, the following equation must be used to evaluate the incident angle modifier.

$$
k \propto \tau=\frac{n+F_{R} U_{L} \frac{T_{f, i}-T_{a}}{I}}{F_{R}(\alpha \tau) n}
$$

where

$\mathrm{F}_{\mathrm{R}} \mathrm{U}_{\mathrm{L}}$ is the negative of the slope determined from the thermal efficiency curve, without a cover plate.

Table III shows that the inlet liquid temperatures were all within $\pm 2^{\circ} \mathrm{F}$ of ambient air temperature. Hence, equation (1) was used for evaluation.

$$
\mathrm{K} \alpha \tau=\frac{n}{0.414}
$$

The results of this computation are shown on Table III and plotted against incident angle in Figure 7. 
7.3 Incident Angle Modifier Test (Continued)

The purpose of the incident angle modifier is to allow a designer or analyst to predict the total daily energy output from the collector, as the sun tracks from east to west. Most collectors are more efficient at normal incidence than at other angles, but some are even more efficient at angles other than normal. 'he only common ground for comparing collectors should be the "all day efficiency" rather than $F_{R} \boldsymbol{\alpha} \tau$. However, the prospective application of the collector also influences the value of "all day efficiency." That is, for low temperature applications such as space heating or domestic hot water, a typical flat plate collector may have an all day effi-ciency of $40 \%$, but for solar cooling applications the all day efficiency might be 208 . Therefore, criteria should be established to rate each collector for space heating, domestic hot water, and solar cooling at a nominal location, berause efficiencies are also dependent on outdoor ambient temperatures.

Evacuated tubes are effective for solar cooling applications; therefore, according to the procedure in NBSIR 78-1305A the all day efficiency of the sunmaster collector is 33 per cent for a typical solar cooling application. The selected site dependent data in conjunction with test data used in these determinations is shown in Table $V$. No standard criteria has been established for "all day efficiency"; and these calculations are dependent un system operating parameters, site data, time of year and daily weather; therefore, the above information should be viewer as interesting but not coriclusive. 
THERMAL PERFORMANCE TEST DATA

FOR THE DEC-8 SUNMASTER COLLECTOR

Sheet 1 of 2 .

\begin{tabular}{|c|c|c|c|c|c|c|c|c|c|c|c|c|c|c|c|}
\hline $\begin{array}{l}\text { Ambient Air Temper- } \\
\text { ature. }\left(T_{a}\right), a_{E}\end{array}$ & 68.5 & 68.5 & 71.4 & 69.8 & 73.2 & 73.7 & 69.8 & 70.5 & 71.1 & 73.0 & 68.8 & 77.2 & 77.7 & 77.0 & 76.6 \\
\hline $\begin{array}{l}\text { Eluid Inlet lemper- } \\
\text { ature }\left(T_{i}\right),{ }^{\circ} F\end{array}$ & 66.9 & 71.1 & 73.4 & 70.7 & 73.7 & 73.3 & 112.6 & 113.4 & 114.1 & 112.9 & 114.0 & 148.7 & 349.3 & 149.0 & 149.5 \\
\hline $\begin{array}{l}\text { Fluid outlet Temp- } \\
\text { erature }\left(\mathrm{T}_{\mathrm{e}}\right),{ }^{\circ} \mathrm{F}\end{array}$ & 90.1 & 86.0 & 95.9 & 88.9 & 99.7 & 94.5 & 113.7 & 136.2 & 132.6 & 142.0 & 134.5 & 166.7 & 164.0 & 269.5 & 66.5 \\
\hline $\begin{array}{l}\text { Differential Eluid } \\
\text { Temperature }(\Delta T),{ }^{\circ} F\end{array}$ & 23.2 & 14.9 & 22.5 & 18.2 & 26.0 & 21.2 & 21.1 & 22.8 & 18.5 & 29.1 & 20.5 & 18.0 & 14.7 & $20.5^{1}$ & 17.0 \\
\hline $\begin{array}{l}\text { Total Solar Flux } \\
\text { (I), BmU/Hr } F \div 2\end{array}$ & 249 & i & 4 & 304.4 & 348. & 348 & 249 & 300 & 300.9 & 346 & 341 & 248 & 5248 & 298 & 298 \\
\hline $\begin{array}{l}\text { Flow Rate, } \\
\text { GPM }\end{array}$ & .18 & .244 & .193 & .246 & .189 & .246 & .175 & .175 & .25 & .160 & .25 & .192 & .240 & .190 & 238 \\
\hline $\begin{array}{l}\left(T-i-T_{a}\right) / \frac{T}{2} \\
\stackrel{E}{E} \cdot H r \cdot F t\end{array}$ & 0 & 0.0105 & 0.006 & 0.003 & 0.001 & 0 & 0.172 & 0.143 & 0.143 & 0.115 & 0.132 & 20.288 & 30.288 & 0.242 & p. 244 \\
\hline $\begin{array}{l}\text { EEficiency } \\
(x), \frac{8}{8}\end{array}$ & 43.3 & 42.6 & 41.5 & 42.8 & 41.0 & 43.5 & 39.0 & 34.9 & 940.8 & 39.1 & 40.1 & 40.5 & 41.3 & 38.0 & 39.5 \\
\hline Inclination Angle & $6^{\circ}$ & $6^{\circ}$ & $6^{\circ}$ & $6^{\circ}$ & $6^{\circ}$ & $6^{\circ}$ & $6^{\circ}$ & $6^{\circ}$ & $6^{\circ}$ & $6^{\circ}$ & $6^{\circ}$ & $6^{\circ}$ & $6^{\circ}$ & $6^{\circ}$ & $6^{\circ}$ \\
\hline
\end{tabular}


TABLE I

(Continued)

THERMAL PERFORMANCE TEST DATA

FOR TAE DEC-8 SUNIASTER COLLECTOR

Sheet 2 of 2 .

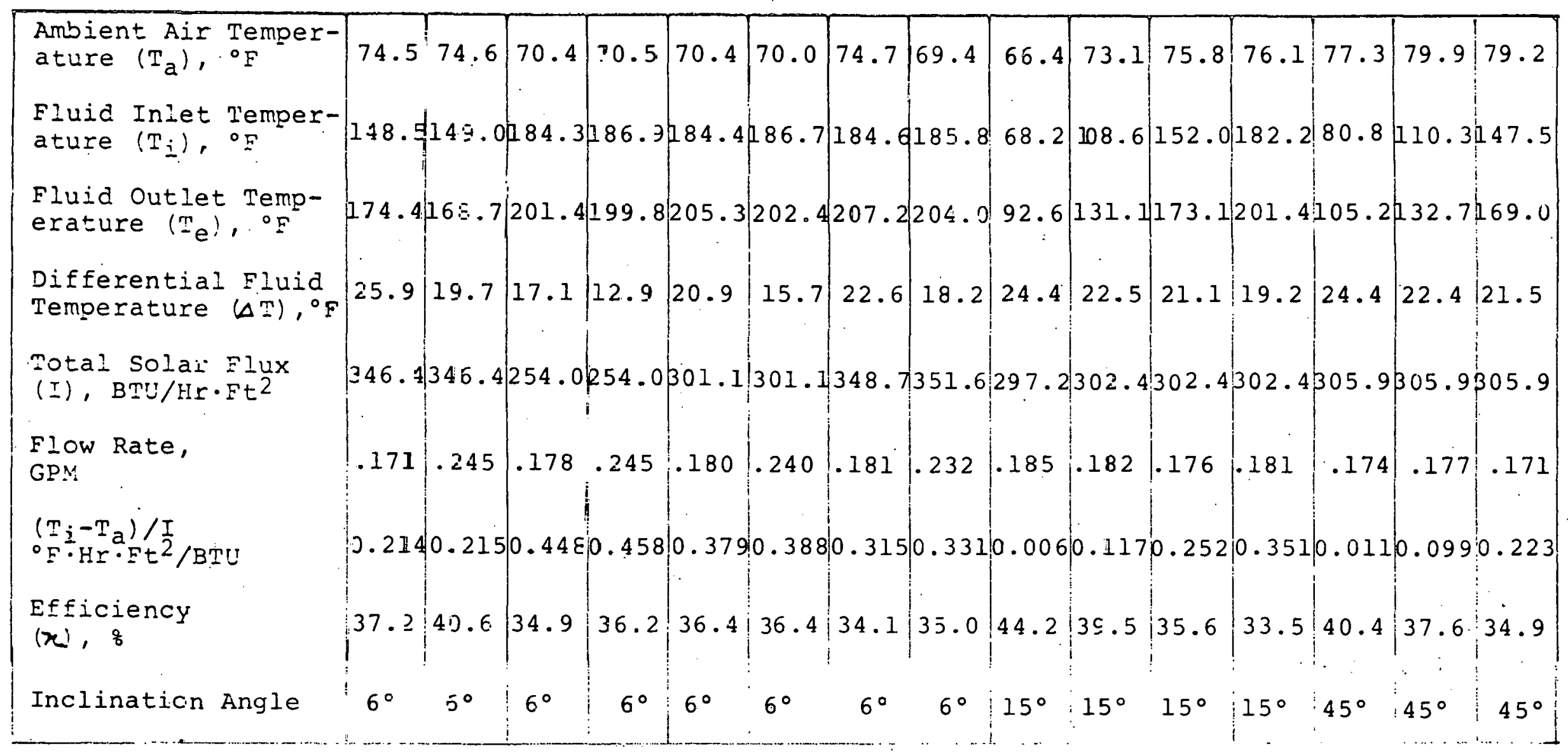


TABLE II

THERMAL PERFORMANCE TEST DATA

FOR THE DEC-8A SUNMASTER COLLECTOR

Sheet 1 of 2 .

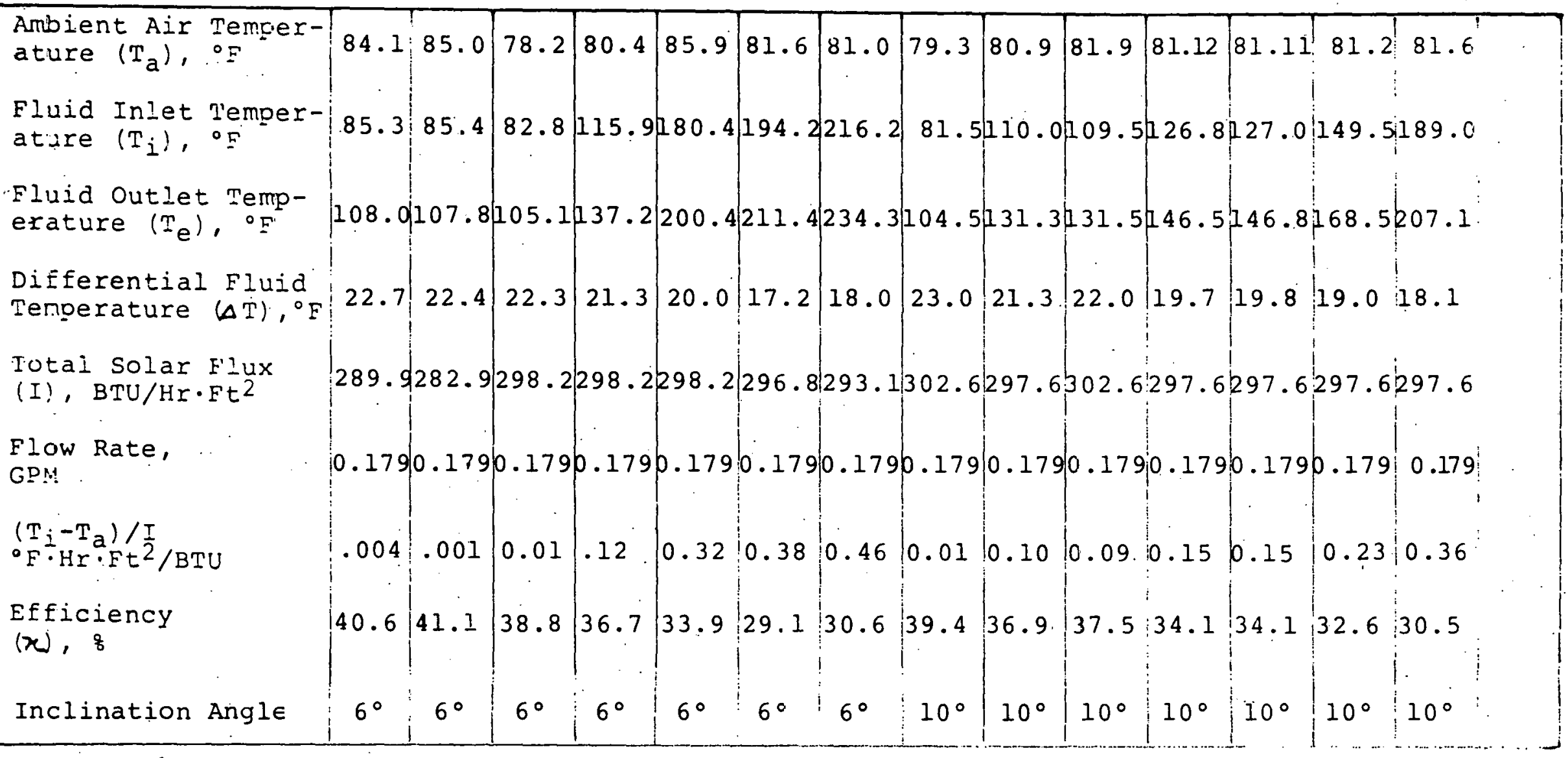


THERMAL PERFORMANCE TEST DATA

EOR THE DEC-8A SUNMASTER COLLECTOK

Sheet 2 of 2

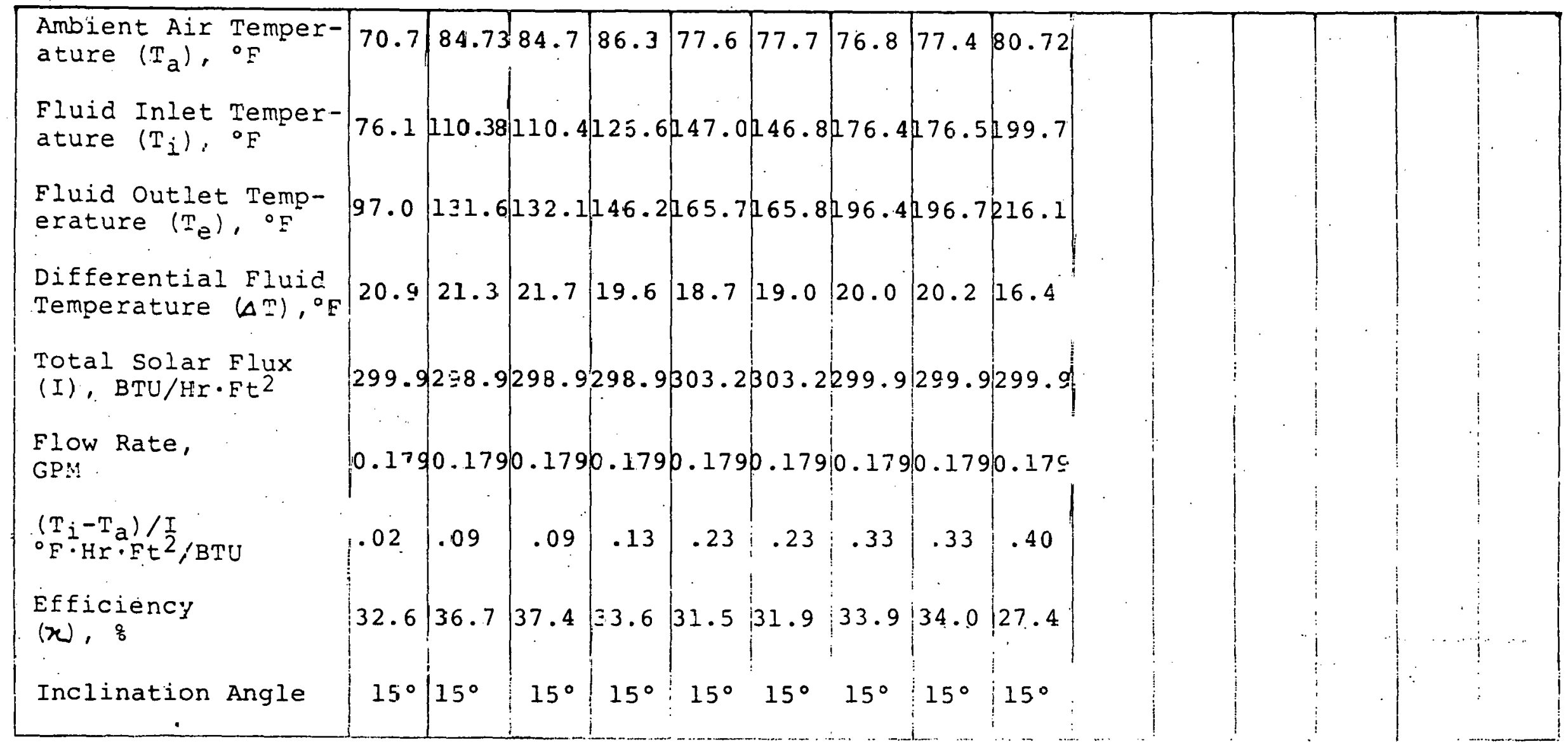


TABLE III

INCIDENT ANGLE MODIFIER TEST DATA

FOR THE DEC-3A SUIMASTER COLLECTOR

\begin{tabular}{|c|c|c|c|c|c|c|}
\hline Ang le & $0^{\circ}$ & $15^{\circ}$ & $30^{\circ}$ & $45^{\circ}$ & & \\
\hline $\begin{array}{l}\text { Ambient Air Fempera- } \\
\text { ture }\left(\mathrm{T}_{\mathrm{a}}\right),{ }^{\circ} \mathrm{F}\end{array}$ & 85.0 & 78.4 & 79.2 & 75.9 & & \\
\hline $\begin{array}{l}\text { Eluid Iniet Tempera- } \\
\text { ture }\left(\mathrm{T}_{i}\right),{ }^{\circ} \mathrm{F}\end{array}$ & 85.4 & 79.6 & 79.6 & 77.3 & & \\
\hline $\begin{array}{l}\text { Fluid Outlet Temp- } \\
\left.\text { erature ( } T_{e}\right),{ }^{\circ} \mathrm{F}\end{array}$ & 107.8 & 104.8 & .104 .6 & 97.6 & & \\
\hline $\begin{array}{l}\text { Differential Fluid } \\
\text { Temperature }(\Delta \mathrm{T}),{ }^{\circ} \mathrm{F}\end{array}$ & 22.4 & 25.2 & 25.0 & 20.3 & & \\
\hline $\begin{array}{l}\text { motal Solar Elux } \\
\text { (I), BTU/Lr. } E \pm 2\end{array}$ & 282.9 & 295.3 & 277.5 & 229.2 & & \\
\hline Flow Rate, GPM. & 0.180 & 0.180 & 0.180 & 0.180 & & \\
\hline $\begin{array}{l}\text { Efficiency } \\
(x), \frac{\circ}{6}\end{array}$ & 41.4 & 44.3 & 46.8 & 45.7 & & \\
\hline $\begin{array}{l}\text { Adjusted } E \pm f i=i e n c y \\
\text { Ratio Kd }\end{array}$ & 1.00 & 1.070 & 1.130 & $1 . .104$ & & $\therefore$ \\
\hline
\end{tabular}


TABLE IV

SUINMASTER DEC-8

HOT FILL TUBE BREAKAGE CONDITIONS

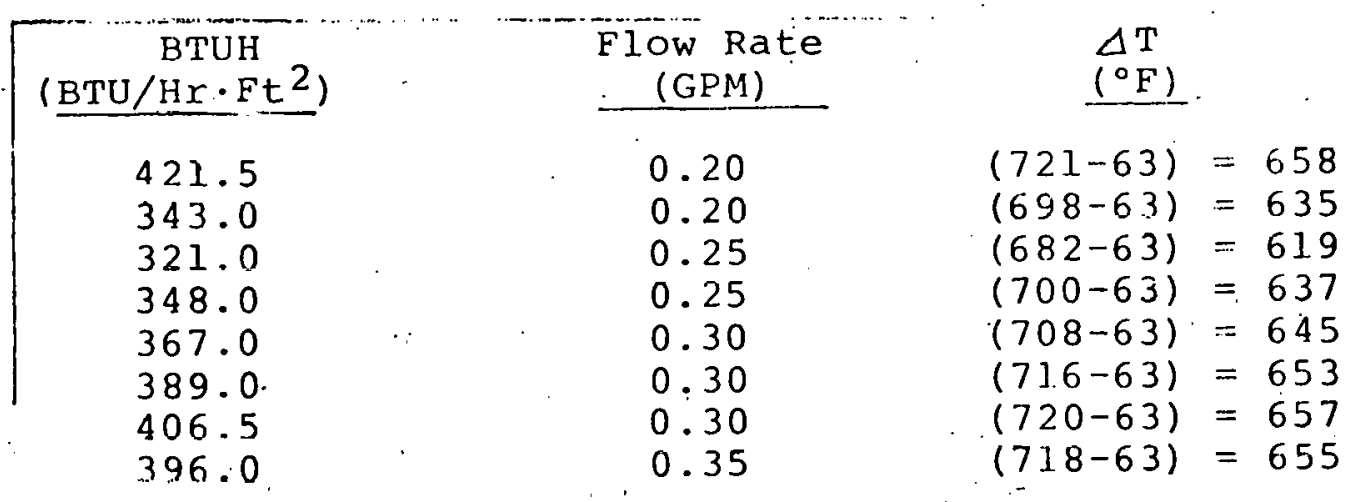


TABLE $\mathrm{V}$

SUNMASTER COLLECTOR

CALCULATED ALL DAY EFFICIENCY

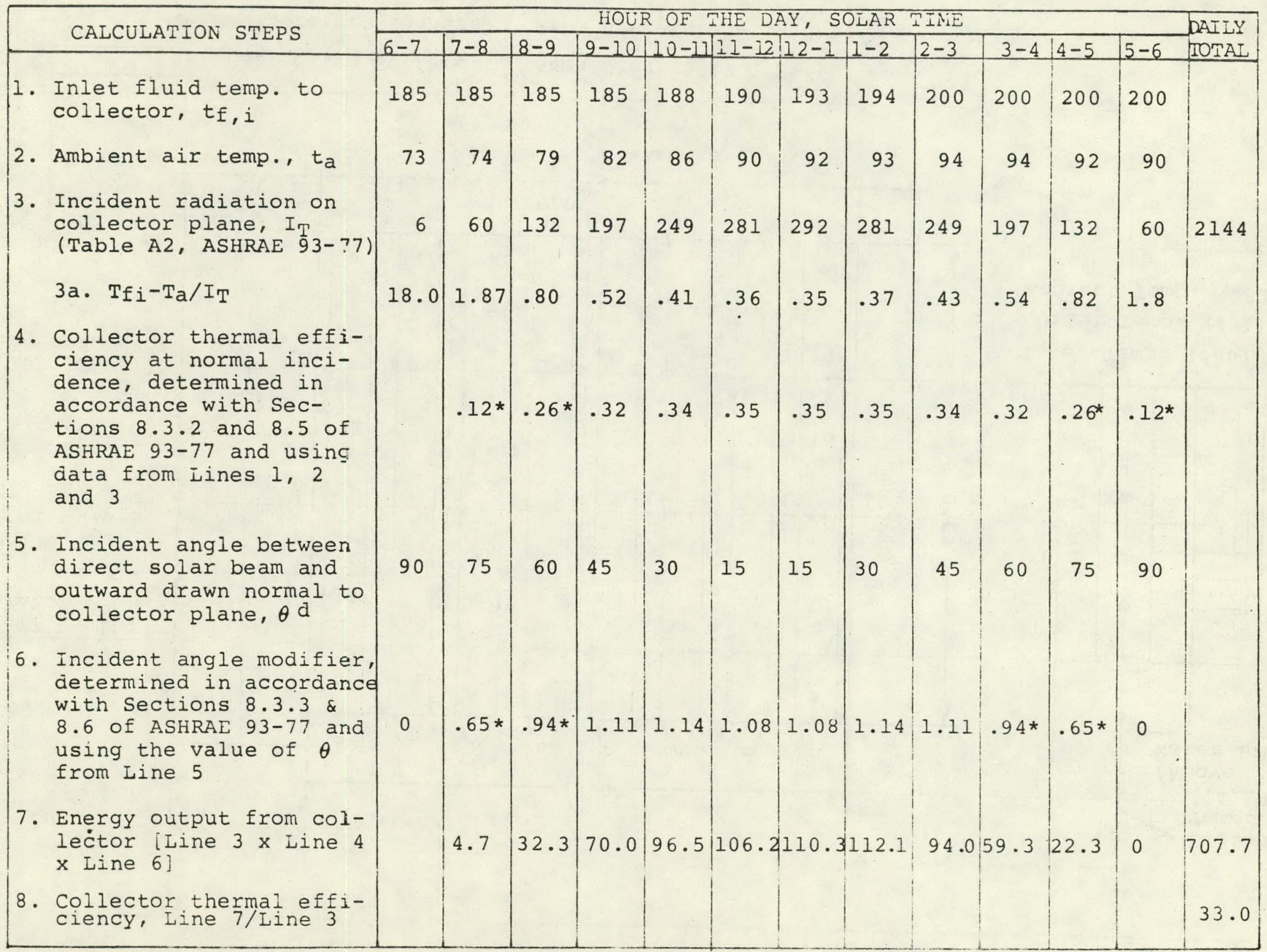

Example: $32^{\circ} \mathrm{N}$ Lat

* Estimated or extrapolatec values 


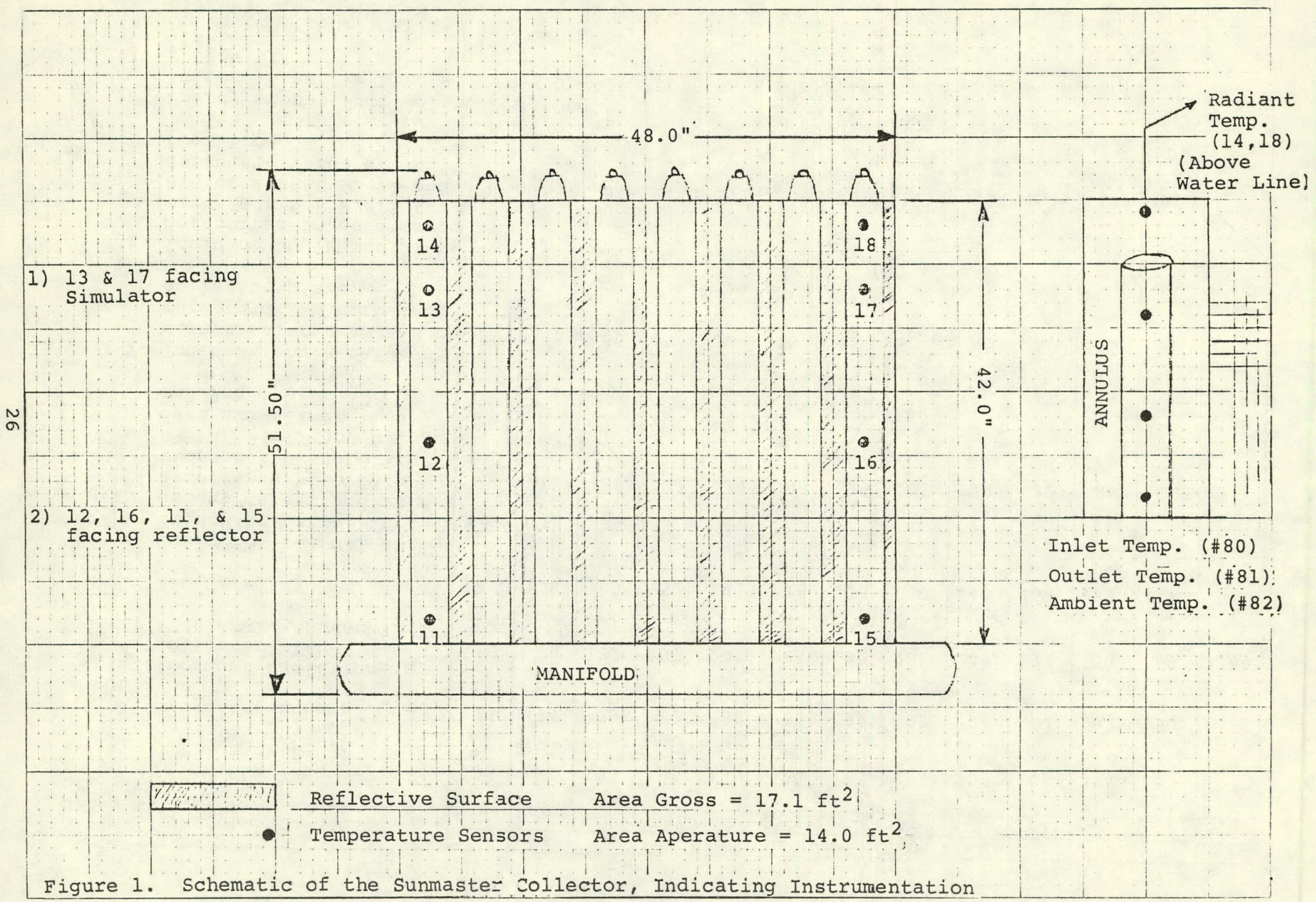




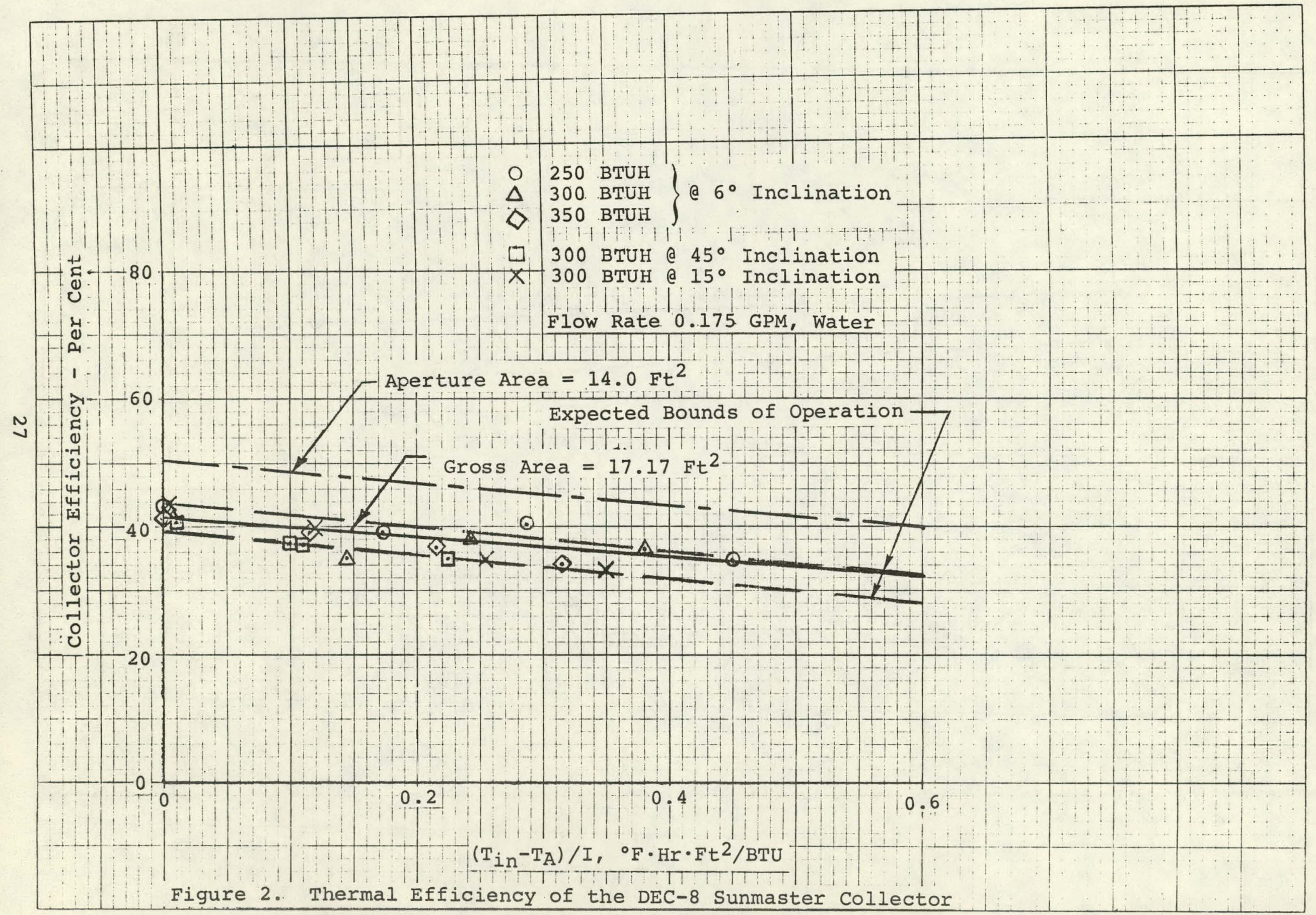




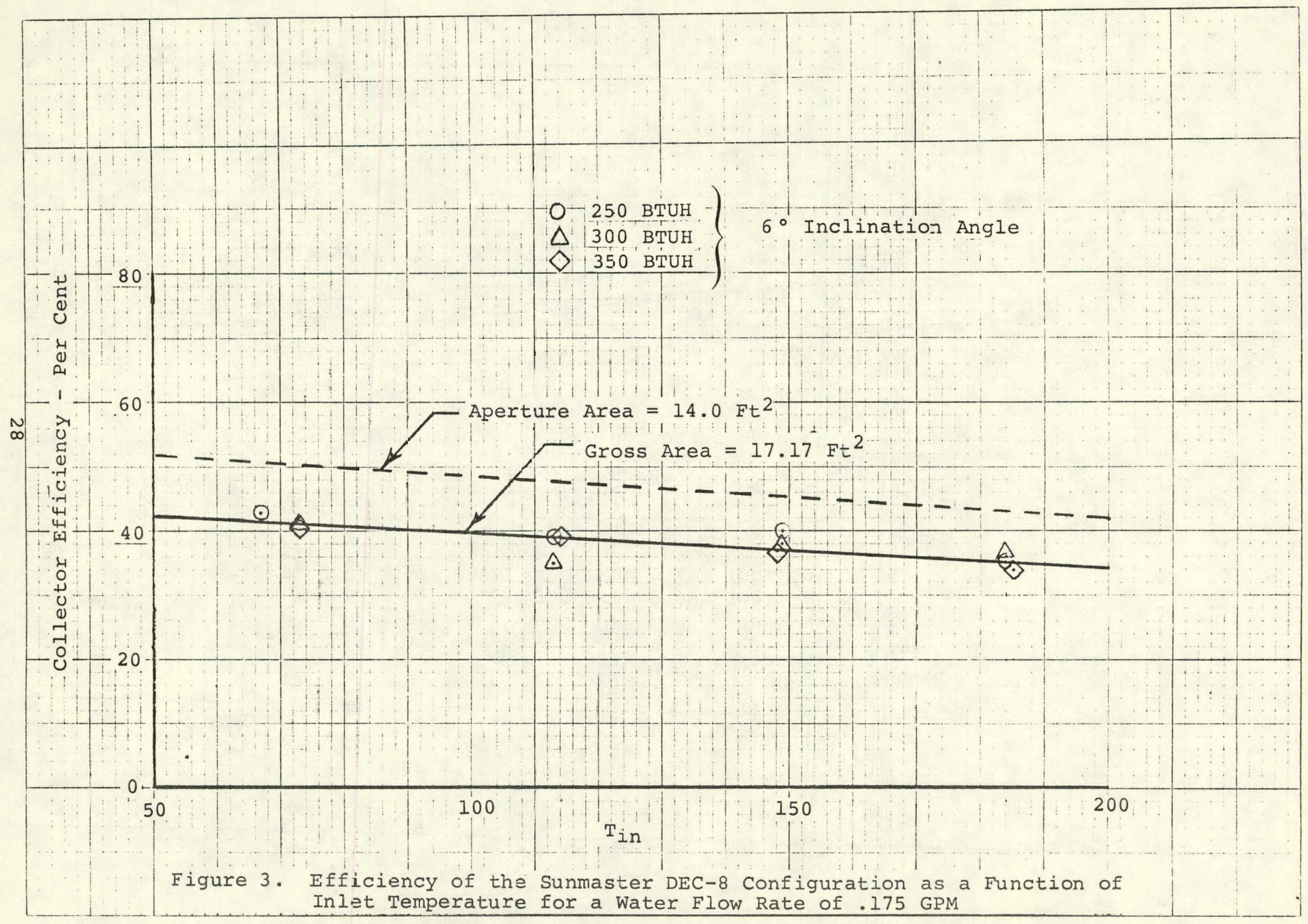




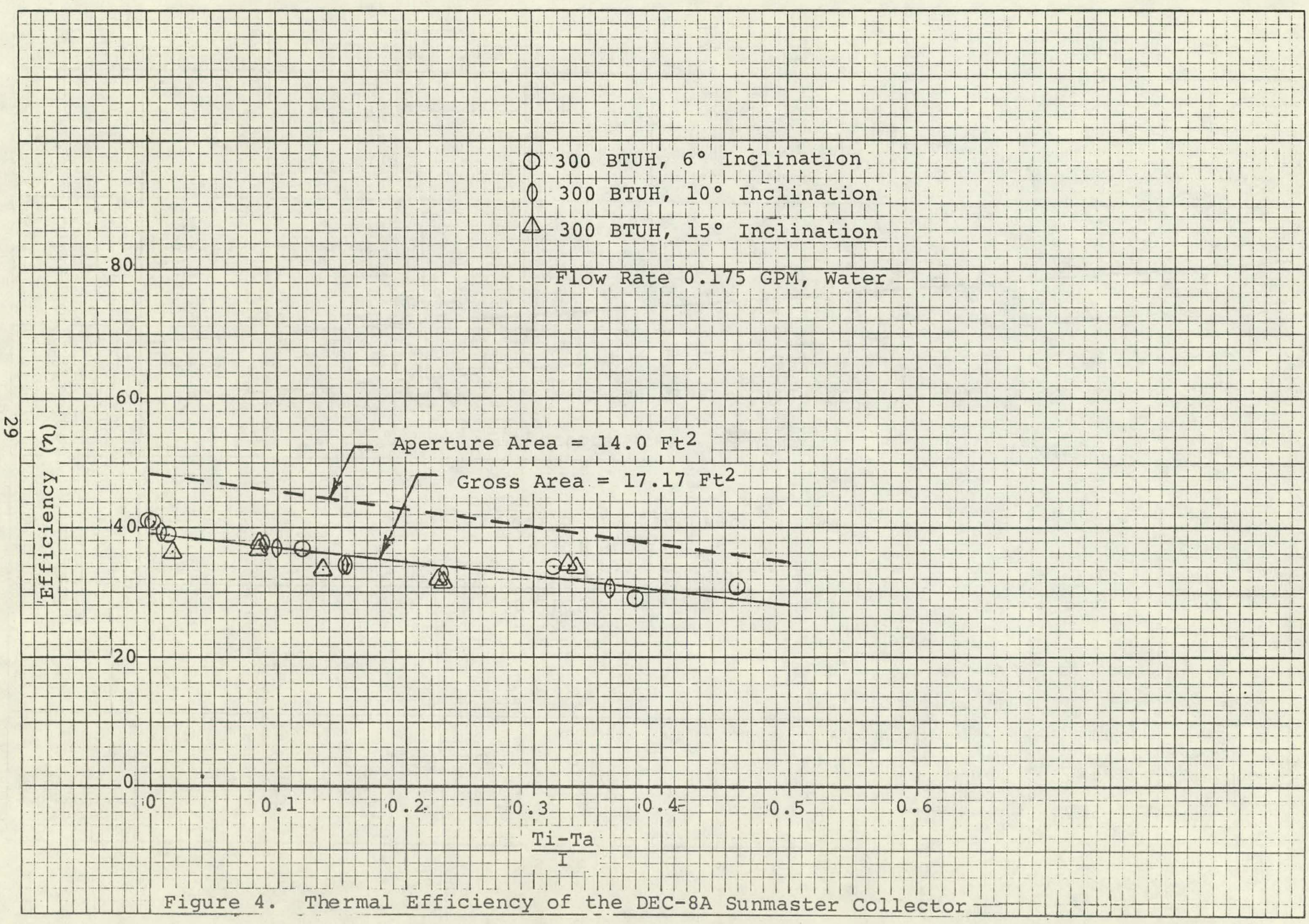




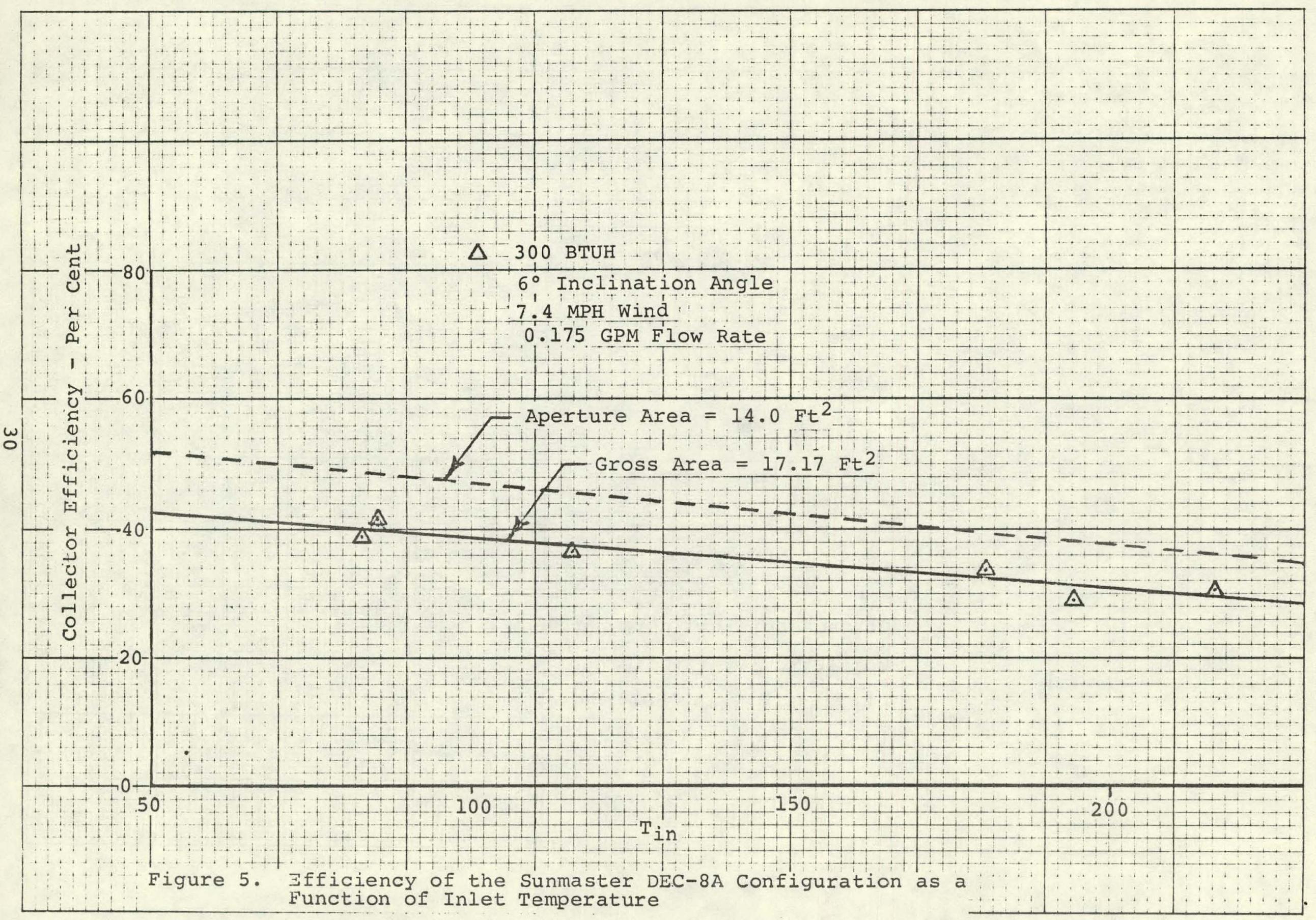




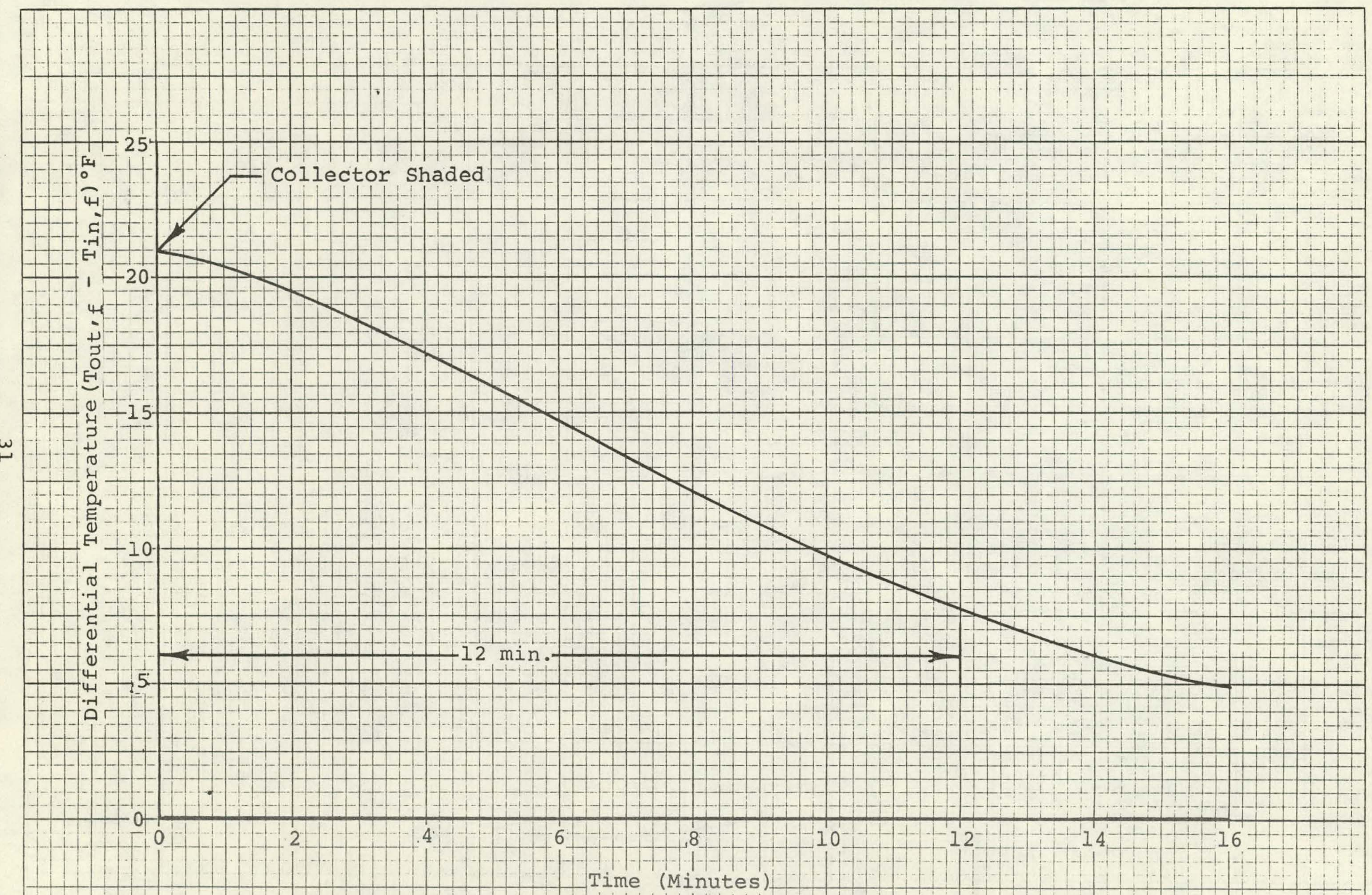

Figure 6. Time Constant Test for the Sunmaster DEC-8A Configuration at 0.175 GPM 


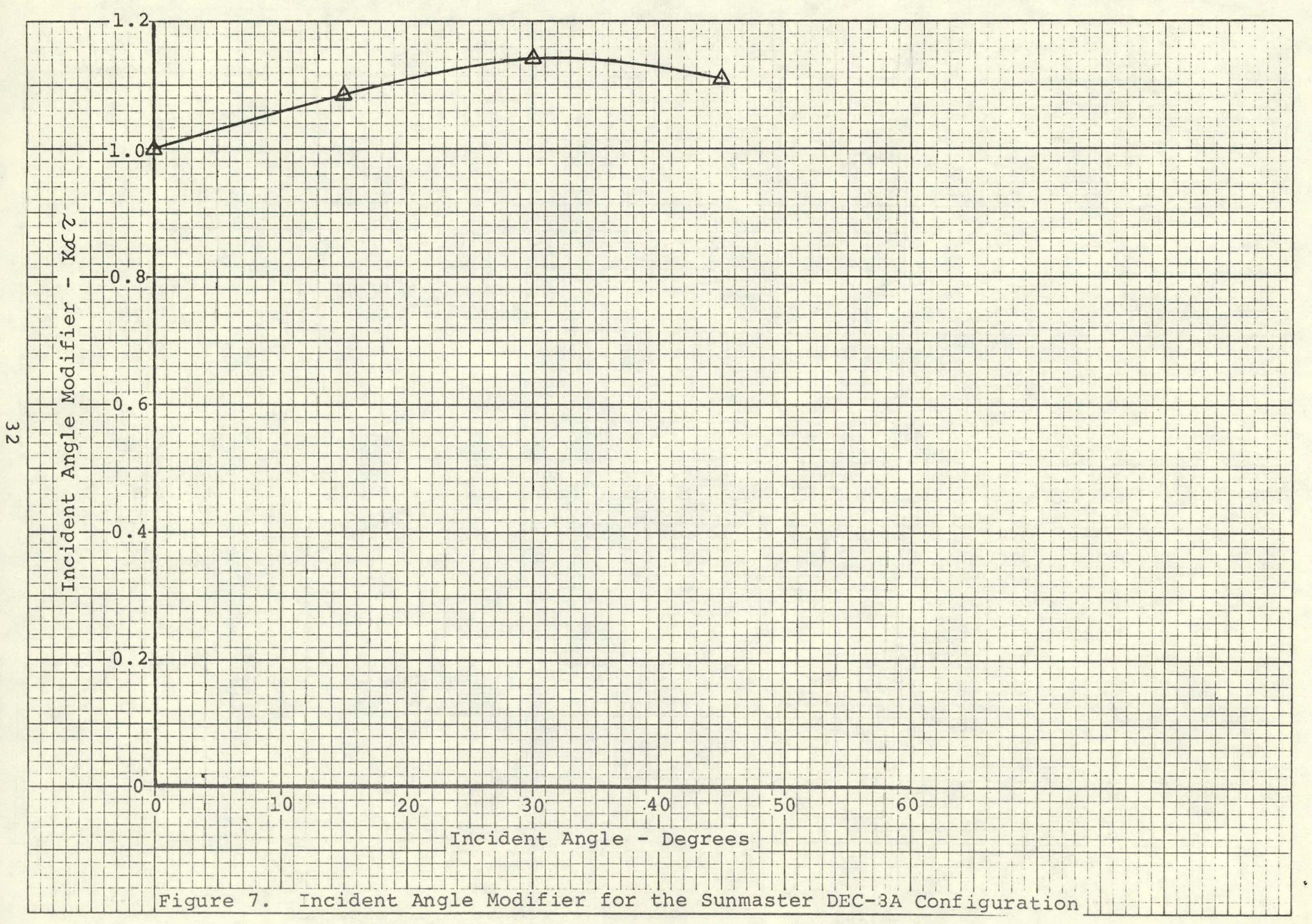




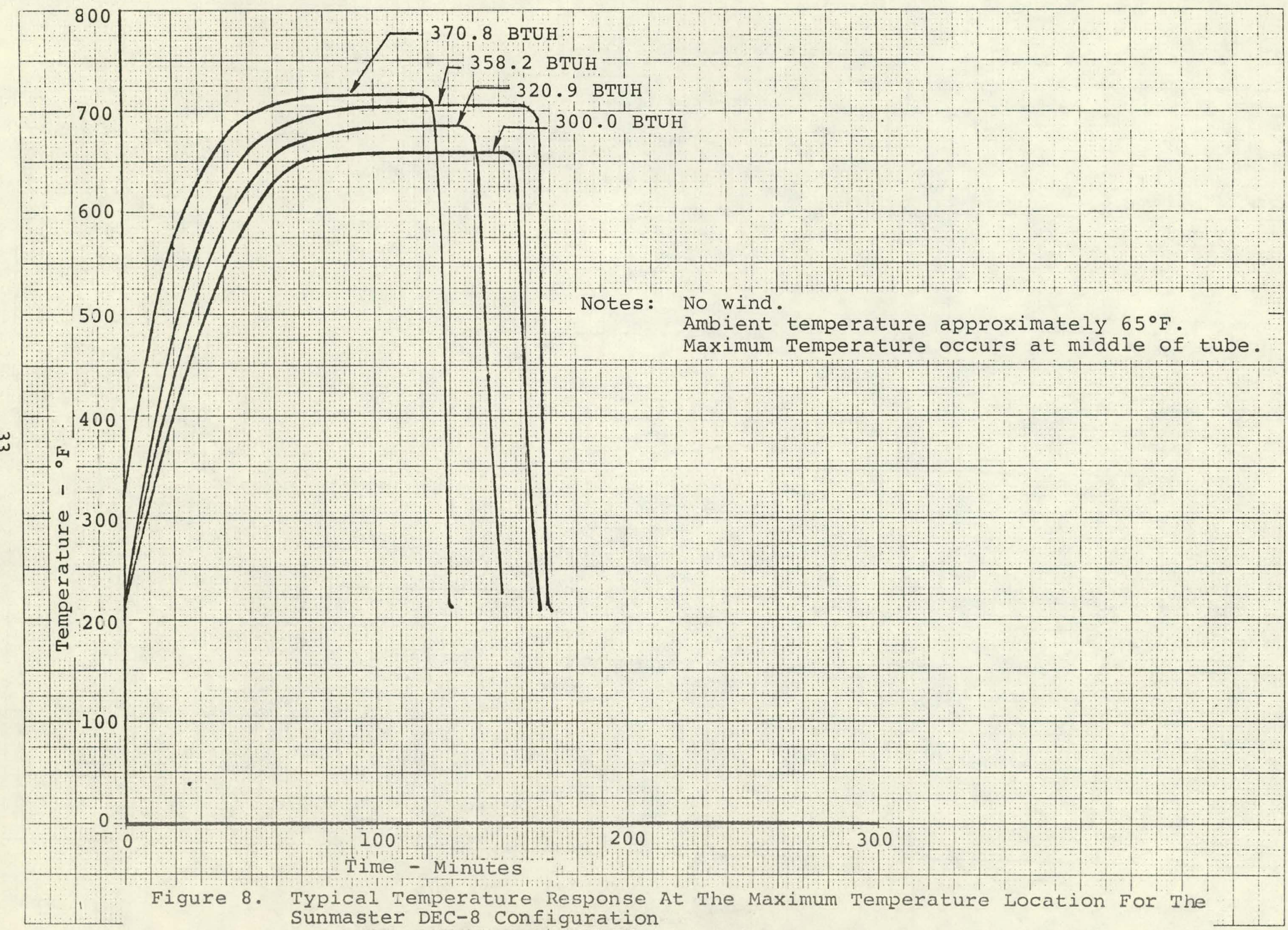




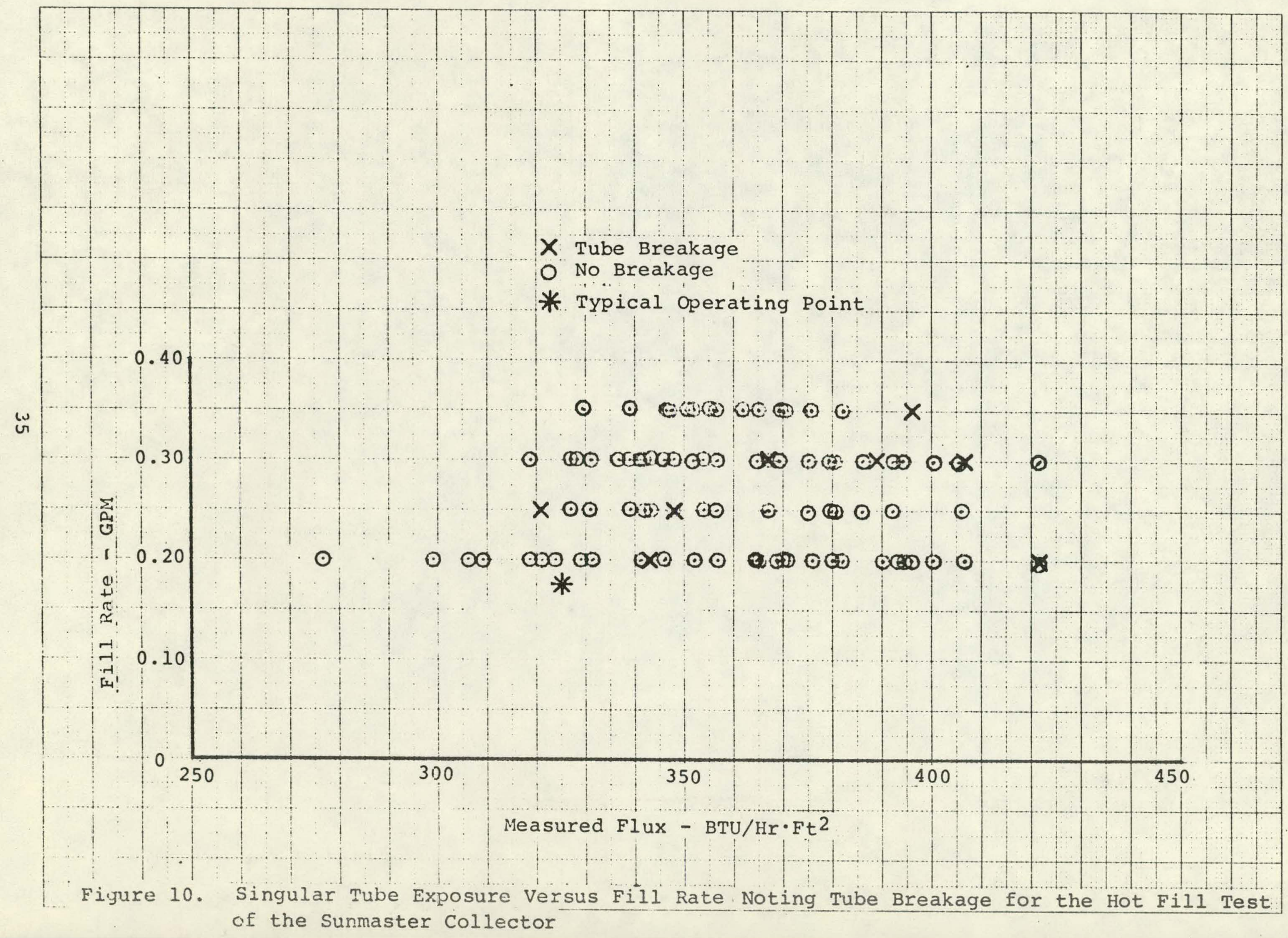

